\title{
Hybrid approach in patients with recurrent brachial artery embolism: adjunctive tissue plasminogen activator infusion following embolectomy
}

\author{
Mete Gürsoy, M.D., Veday Bakuy, M.D., Mehmet Atay, M.D., \\ Jabir Gulmaliyev, M.D., Ahmet Akgül, M.D.
}

Department of Cardiovascular Surgery, Bakirkoy Dr. Sadi Konuk Training and Research Hospital, Istanbul

\begin{abstract}
Acute ischemia of an upper extremity occurs less frequently than vascular events of the leg and accounts for $15 \%-32 \%$ of all cases. Embolectomy provides prompt and effective treatment in the majority of cases. Recurrence of embolism and failed reperfusion can result in poor outcomes, even extremity loss. Adjunctive managements become important in this patient group. In this report, we present percutaneous intraarterial drip tissue plasminogen activator infusion to rescue the extremity in a patient with small cell lung cancer who experienced thromboembolism an additional six times following embolectomy.
\end{abstract}

Key words: Embolectomy; recurrent brachial artery embolism; tissue plasminogen activator.

\section{INTRODUCTION}

Acute ischemia of an upper extremity occurs less frequently than vascular events of the leg and accounts for 15\%-32\% of all cases. Embolism, usually cardiac, is the most common etiologic factor, with an incidence range of $58-93 \% .^{[1,2]}$ The brachial artery is a frequently occluded vessel. Atrial fibrillation is responsible in the majority of patients with cardiac embolism. Malignant tumor-related acute extremity ischemia is a rare but well-analyzed entity. ${ }^{[3]}$ Malignancy may trigger predisposition to hypercoagulability. On the other hand, cardiac myxoma and non-cardiac tumors invading the left atrium or pulmonary veins may cause fragmented mass embolism directly. Conventional embolectomy promptly restores blood flow in the majority of cases. Alternative approaches are necessitated rarely in cases in which embolectomy is unable to provide reperfusion. ${ }^{[4]}$

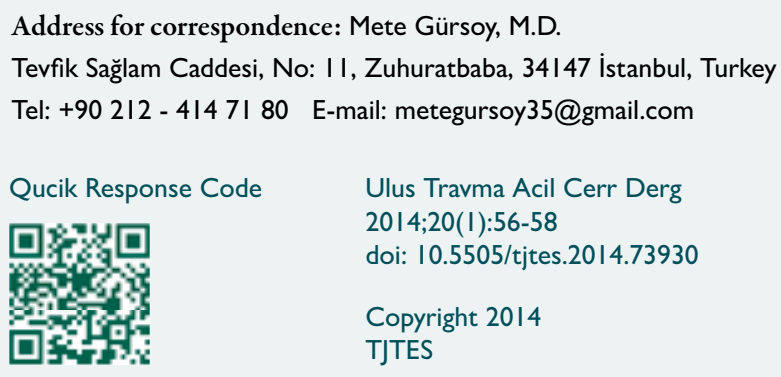

In this report, we present intraarterial drip infusion of tissue plasminogen activator following surgery in a patient with small cell lung cancer.

\section{CASE REPORT}

A 46-year-old man with a diagnosis of small cell lung cancer was admitted to our institution with pain and coldness at the distal right upper extremity. On the physical examination, the extremity was found cold and cyanotic, and radial and ulnar pulses were not palpable. Doppler ultrasonography showed triphasic flow in the brachial artery and hyperechogenic thrombus material in the proximity of the radial and ulnar arteries. The patient underwent brachial and selective radial and ulnar embolectomy under local anesthesia. Fresh arterial thrombus was removed. Distal blood flow recovered promptly. Routine heparin, prostacyclin analogue and antiplatelet therapy were started. One day later, we observed weak radial and ulnar pulses and the patient complained of pain again. Brachial embolectomy was performed an additional six times. Subclavian artery stenosis was excluded with computerized tomography (CT) angiography (Fig. la). Although coagulation parameters were found to be normal, dual antiplatelet and warfarin were initiated, but could not prevent recurrence of thromboembolism. The treatment strategy was re-considered and intraarterial drip infusion of tissue plasminogen activator was planned. In the last operation, the brachial artery was repaired with saphenous vein patch plasty technique following embolectomy. Intraarterial 


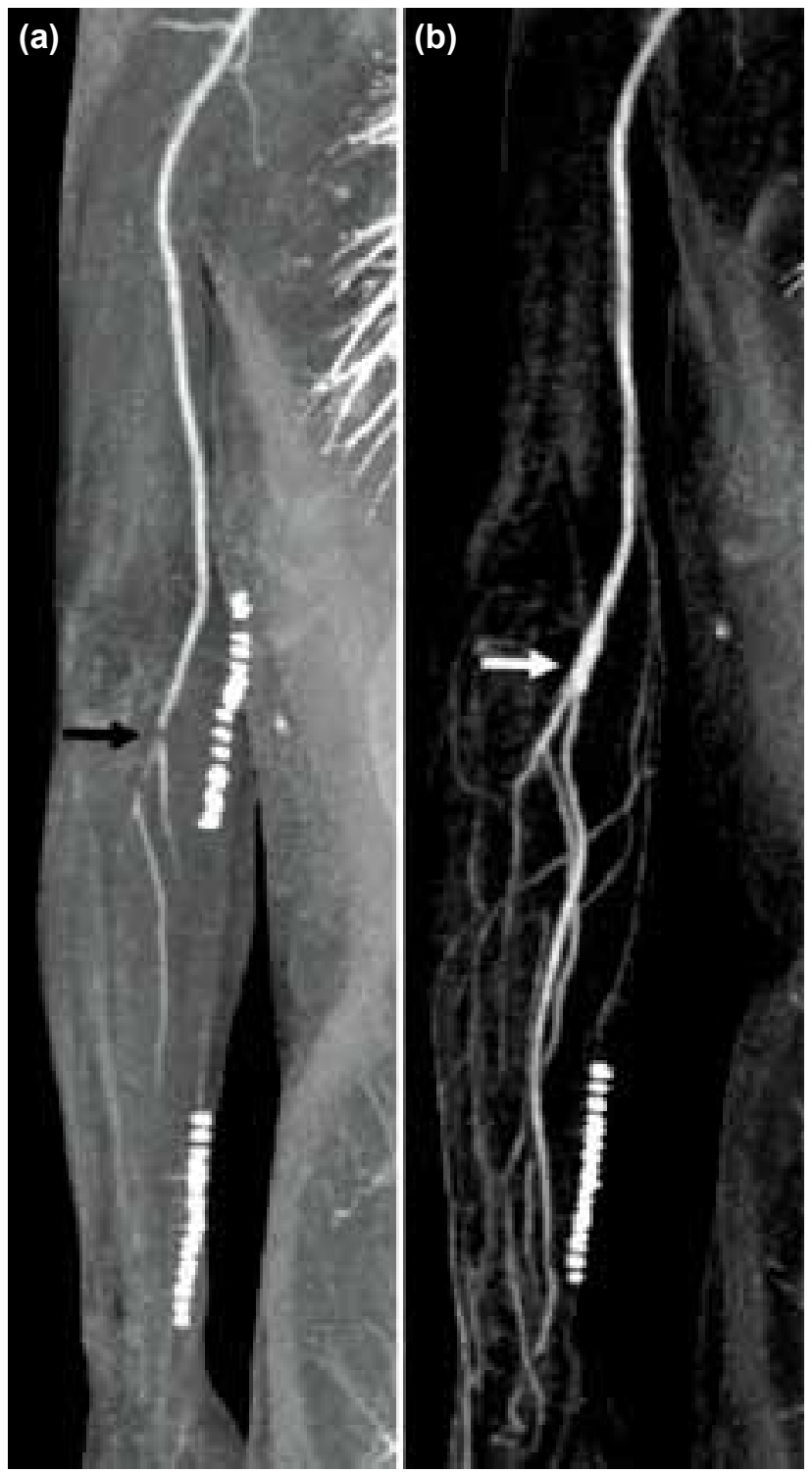

Figure 1. (a) Preoperative CT angiography shows brachial artery occlusion (black arrow indicates occluded brachial artery). (b) Postoperative CT angiography shows patent upper extremity arteries (white arrow indicates repaired brachial artery segment).

tissue plasminogen activator infusion was started and continued for 24 hours via percutaneous $20 \mathrm{G}$ intraarterial catheter, which was introduced approximately $2 \mathrm{~cm}$ proximal to the lesion. Warfarin and dual antiplatelet therapy were also continued. The follow-up examination revealed palpable radial and ulnar pulses on subsequent days. The patient was discharged well. CT angiography showed patent brachial, radial and ulnar arteries at the 6th week follow-up (Fig. Ib).

\section{DISCUSSION}

Acute arterial embolism can be treated with conventional thromboembolectomy in the majority of cases. Recurrence of thromboembolic events has a poor prognosis, even limb loss. Acute embolism was found to be responsible in approximately $1 \%$ of upper limb amputations in the United
Kingdom. ${ }^{[5]}$ Alternative treatment options are not well documented. To the best of our knowledge, there is no large study analyzing the risk factors for embolism recurrence and failed embolectomy.

Conventional thromboembolectomy depends on mechanical clot removal with balloon catheter. This procedure is able to restore blood flow by recanalizing the arterial lumen, but catheter insertion may cause embolism of thrombus fragments into the distal vascular bed. In addition, distal, small arteries are not accessible by Fogarty catheter. In this context, antithrombotic and anticoagulant therapies become important following thromboembolectomy. Distal obstructed small arteries increase capillary pressure and decrease run-off quality. High resistance and impaired vascular endothelium trigger clot formation and recurrence of ischemia, particularly in patients with hypercoagulability. Aggressive antiplatelet and anticoagulant therapy, peripheral vasodilators, and prostacyclin analogues may be helpful in preventing recurrence in some cases. In the literature, various treatment alternatives have been reported in extreme patients in whom conventional embolectomy and routine medical treatment were unsatisfactory in restoring blood flow.

Intraarterial thrombolytic infusion has been used for a long time in patients with acute ischemic disorders. ${ }^{[6]}$ However, to date, neither indications nor administration technique of thrombolysis is adequately established in acute peripheral ischemia. In theory, thrombolytic agents dissolve thrombocyte-fibrin aggregates in clot formation. Although some authors reported similar results with thrombolysis in comparison to surgery in acute peripheral occlusion, major bleeding risk limits initial administration. In 2009, the Thrombosis Interest Group of Canada emphasized that thrombolysis should be utilized if there is additional distal clot embolization that is difficult to reach surgically and only if there is risk of tissue loss related to systemic adverse effects of tissue plasminogen activators, such as major bleeding. ${ }^{[7]}$ In the same year, Gilani and colleagues ${ }^{[8]}$ reported alternative thrombolytic management avoiding systemic adverse effects. They performed isolated limb perfusion technique with tissue plasminogen activator in a patient suffering acute hand ischemia. In our case, small cell lung cancer appeared to be the triggering factor for recurrence, which has not been well documented previously. ${ }^{[3]}$ Additionally, increased thrombogenic tendency was certain due to the six surgical interventions, which can cause serious endothelial damage. Association of these factors made this case more complex than the general arterial embolism patients. Tissue plasminogen activator might be helpful in the prevention of clot formation on the damaged arterial endothelium in patients with thrombogenic tendency due to malignancy. Furthermore, tissue plasminogen activator may increase run-off quality by dissolving an embolus pushed surgically into the distal small arteries. Therefore, we preferred intraarterial drip thrombolytic infusion via percutaneous catheter for 24 hours to prevent acute thrombosis, and 
we were able to rescue the extremity without any adverse events.

In conclusion, conventional embolectomy remains the gold standard in patients with acute arterial ischemia, but it may not be sufficient in patients with distal embolism. Percutaneous catheter-directed intraarterial thrombolytic therapy may be helpful in selected patient groups.

\section{Conflict of interest: None declared.}

\section{REFERENCES}

1. Vohra R, Lieberman DP. Arterial emboli to the arm. J R Coll Surg Edinb 1991;36:83-5.
2. Eyers P, Earnshaw JJ. Acute non-traumatic arm ischaemia. Br J Surg 1998;85:1340-6. CrossRef

3. Zürcher M, Gerber H, Gebbers JO. Tumor embolism with fatal cerebral infarct in pneumonectomy. Case report and review of the literature. [Article in German] Chirurg 1996;67:959-62. [Abstract] CrossRef

4. Emrecan B, Ozcan AV, Onem G, Baltalarlı A. Subclavian-carotid transposition for subclavian artery stenosis causing recurrent brachial artery embolism: case report. Ulus Travma Acil Cerrahi Derg 2010;16:483-5.

5. Information Services Division NHSScotland on behalf of National Amputee Statistical Database (NASDAB) Edinburgh. Amputee Statistical Database for the United Kingdom; 2006/07 Report.

6. Ouriel K. Thrombolytic therapy for acute arterial occlusion. Curr Opin Gen Surg 1994:257-64.

7. Roussin A, Carter C, Oliva V. Thrombolytic therapy in peripheral arterial disease. The Thrombosis Interest Group of Canada; 2009.

8. Gilani R, Greenberg RK, Johnston DR. Isolated limb perfusion with tissue plasminogen activator for acute hand ischemia. J Vasc Surg 2009;50:659-62. CrossRef

\section{OLGU SUNUMU - ÖZET}

\section{Tekrarlayan brakiyal arter embolisinde hibrid yaklaşım: Embolektomi sonrası perkütan doku plazminojen aktivatörü uygulaması \\ Dr. Mete Gürsoy, Dr. Veday Bakuy, Dr. Mehmet Atay, Dr. Jabir Gulmaliyev, Dr. Ahmet Akgül}

Bakırköy Dr. Sadi Konuk Eğitim ve Araştırma Hastanesi, Kalp ve Damar Cerrahisi Kliniği, İstanbul

Akut üst ekstremite iskemisi alt ekstremitenin vasküler hastalıklarına göre daha nadir olup tüm olguların \% I5-32'sini oluşturur. Embolektomi olguların büyük kısmında hızlı ve etkili tedavi sağlar. Tekrarlayan ve embolektomi ile reperfüzyon sağlanamayan olgularda prognoz kötü olup amputasyonla sonuçlanan olgular bildirilmiştir. Bu hasta grubunda embolektomi ile birlikte ya da sonrasında destekleyici tedaviler önem kazanmaktadır. Bu yazıda küçük hücreli akciğer kanseri hastasında embolektomi sonrası altı kez tekrarlayan brakiyal arter embolisine bağılı kritik üst ekstremite iskemisinde kurtarıcı teknik olarak yavaş perkütan intraarterial doku plazminojen aktivatörü uygulamamızı sunuyoruz.

Anahtar sözcükler: Doku plazminojen aktivatörü; embolektomi; tekrarlayan brakial arter embolisi.

Ulus Travma Acil Cerr Derg 20 I4:20(I):56-58 doi: 10.5505/tjtes.20I4.73930 